\title{
A207 重力を利用した誘電泳動力の測定方法 Measurement of Dielectrophoretic Force by employing Gravitational Force
}

\author{
○今里 浩子（九工大院） \\ 山川 烈（九工大院）
}

Hiroko IMASATO, Graduate School of Life Science and Systems Engineering, Kyushu Institute of Technology Takeshi YAMAKAWA, Graduate School of Life Science and Systems Engineering, Kyushu Institute of Technology

Key Words : Dielectrophoresis, Nonuniform electric field, Null method, Gravitational force

1.はじめに

誘電泳動とは, 不均一電場内におかれた物質が電場とそれ により誘導される双極子モーメントの相互作用により駆動 される現象である.この現象を利用して，現在，生体試料の 分離・同定をはじめ,さまざまな分野で研究が進められてい $ろ^{(1,2)}$. 特定の物質に生じたこの駆動力, すなわち, 誘電泳 動力を測定することは, 極めて重要であるが, その具体的数 值を求めることは容易ではない. 一般に設計された電極によ つて生ずる誘電泳動力を解析的に求めることは不可能に近 いので, 有限要素法を用いて, 計算によって求められる. し かしこれは, 実際の誘電泳動力を測定していることにならな W.

本研究では, どのような形状の電極の場合であっても適用 できる，重力を利用した誘電泳動力の直接的測定方法を提案 する. 実際にマイクロ加工技術を利用してデバイスを試作し， その中でポリスチレンビーズに生じる負の誘電泳動力の測 定を実施した.

\section{2. 測定原理}

比誘電率 $\varepsilon_{m}$ の溶液中における比誘電率 $\varepsilon_{p}$ の粒子(半径 $\mathrm{r}$ の球体) が不均一な電界から受ける誘電泳動力は,下記のよう にあらわすことができる(3).

$$
F_{D E P}=2 \pi \varepsilon_{0} \varepsilon_{m} r^{3} \frac{\varepsilon_{p}-\varepsilon_{m}}{\varepsilon_{p}+2 \varepsilon_{m}} \nabla E_{r m s}^{2}
$$

この誘電泳動力を測定するために ‘零位法”を用いる.す なわち, 重力を利用して, (1)式に等しい逆向きの力を作る. そのためには，Fig. 1 に示すように水平面と $\theta$ の角をなす斜 面に沿って上向きに負の誘電泳動力が発生するように, 斜面 にデバイスをセットする必要がある. デバイス中の水に分散 した粒子の斜面に沿った下向きの重力は,

$$
F_{G}(\theta)=\frac{4}{3} \pi r^{3}\left(\rho_{p}-\rho_{m}\right) g \sin \theta
$$

となる. $F_{D E P}=F_{G}(\theta)$ となるように $\theta$ を調整すれば，(2)式よ り $F_{D E P}$ が計算によって求まる. また， $F_{D E P}$ と $F_{G}(\theta)$ が互い に打ち消しあう方向でない場合は, Fig. 1 の $\varphi$ 方向に回転さ せることによって，打ち消しあうように $F_{G}(\theta)$ の方向を調整 することができる.

\section{3. 実験}

\section{1 実験試料}

誘電体粒子としてポリスチレンビーズ $\left(9.9 \mu \mathrm{m}^{\phi}\right.$, 比重 1.06 , 誘電率2.4 2.65, Duke Scientific Co., Ltd.) を使用し, 蒸留水 中に浮遊させた。

\section{2 デバイス作製}

スライドグラス表面に厚さ約 $1 \mu \mathrm{m}$ のアルミニウム薄膜を スパッタで形成し，フォトリソグラフィにて電極を作製した. さらに, 電極の表面全体を厚さ約 $1 \mu \mathrm{m}$ の感光性ポリイミド （フォトニース，東京応化工業）で被覆した. 約 $100 \mu \mathrm{m}$ の シリコンゴム膜をスペーサとして円形のチャンバーを形成 し, 実験試料を注入し, カバーグラスで覆った。（Fig. 2 参 照)

\section{3 実験装置}

誘電泳動実験を顕微鏡下で行うためにデバイスを顕微鏡 にセットし， $\theta$ および $\varphi$ を独立に調整できるような可変式傾 斜台を試作し，これに顕微鏡を固定した（Fig。3）

\section{4 実験方法および結果}

ファンクションジェネレータからデバイスに供給する正 弦波信号の電圧振幅および周波数ならびに角度 $\theta$ を変え, ス テップ応答および静特性を測定した.

\section{(1)ステップ応答}

電圧ステップ応答を計測した. 各入力信号をステップ状に 変化させ，ポリスチレンビーズの移動量を記録した。ポリス チレンビーズの静止が物理吸着や摩擦によるものでないこ とを確認したうえで, その定常状態を確定した. ステップ電 圧は，8Vppから 20Vppに，また 20Vpp から 8Vppに切り替え て行った。 その場合の結果を Fig. 4 に示す.この図から時 定数はそれぞれ 1 分および 5 分で, およそ 15 分で定常状態 に達することがわかる。

\section{(2)静特性}

電圧および角度を変化させた場合のポリスチレンビーズ の移動量を定常状態になるのを待って測定した. その結果を それぞれ，Fig. 5 および Fig. 6 に示す. 電圧が高くなる につれて, 負の誘電泳動力が増大し, 重力に抗してポリスチ レンビーズが上方に移動していることがわかる．また，斜面 の角度の増大に伴い, 重力成分が増加し, 上方への誘電泳動 カが抑えられ，ボリスチレンビーズは下方へ移動する.ここ で $10^{\circ}$ は $0.05 \mathrm{pN}$ を, $60^{\circ}$ は $0.259 \mathrm{pN}$ を意味する.

\section{4. 結論}

マイクロ加工技術により誘電泳動用のデバイスを作製し, さらに, 重力の方向が調整可能である可変式傾斜台を作製し た.これらを使用することにより, 負の誘電泳動力によるポ リスチレンビーズの移動のステップ応答および静特性を測 定した。この試作装置により，0.03 p Nから $0.259 \mathrm{pN}$ 程度の 誘電泳動力の測定が可能である.

日本機械学会〔No.07-35] 第18回バイオフロンティア講演会講演論文集（'07.10.6〜7 福岡市） 


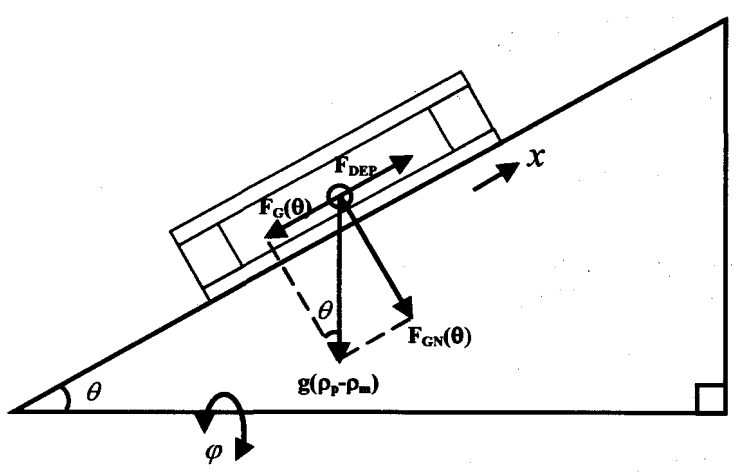

Fig. 1 誘電泳動力をポリスチレンビーズの重力を用いて測定する 装置の説明図

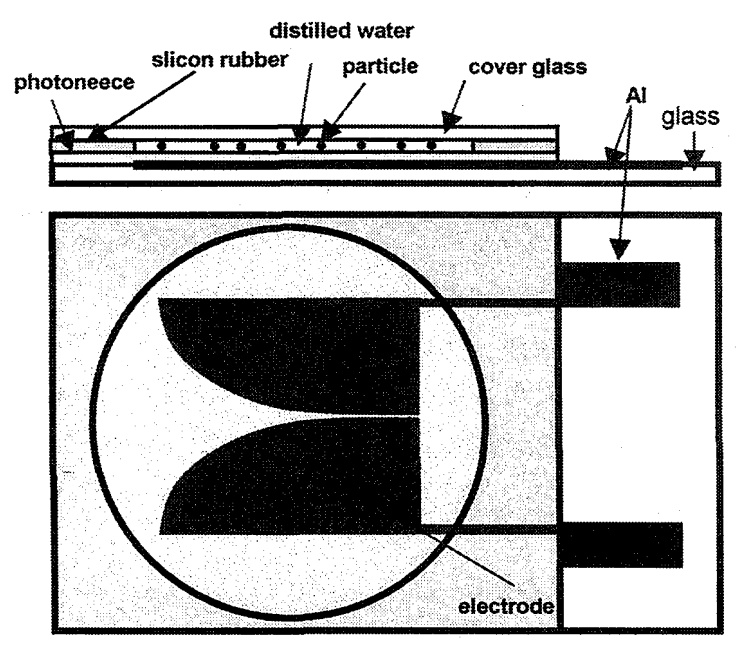

Fig. 2 誘電泳動実験用デバイス

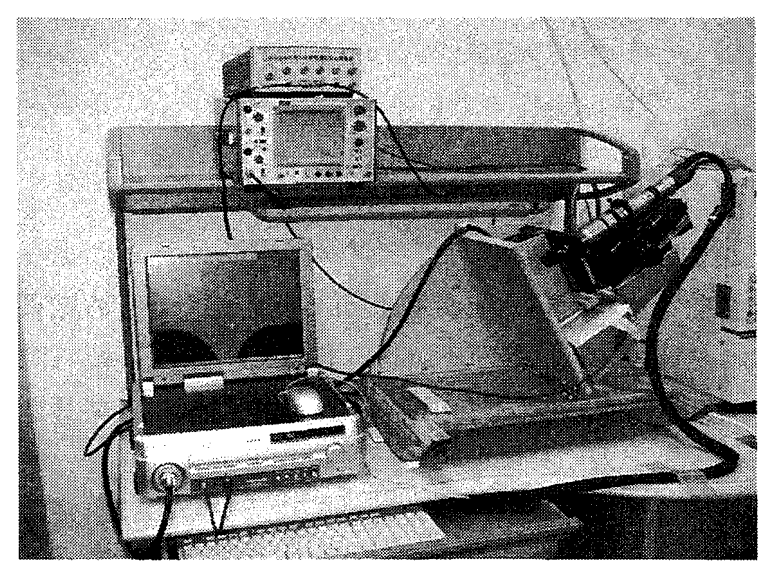

Fig. 3 実験装置外観
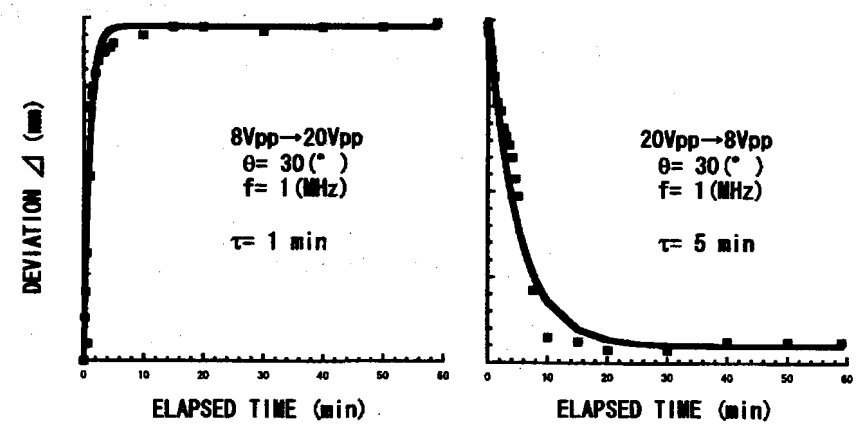

Fig. 4 ポリスチレンビーズの位置のステップ電圧に対する応 答

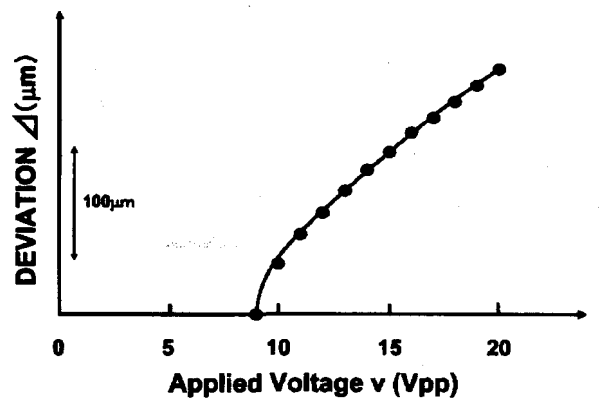

Fig. 5 ポリスチレンビーズの位置の印加電圧依存性

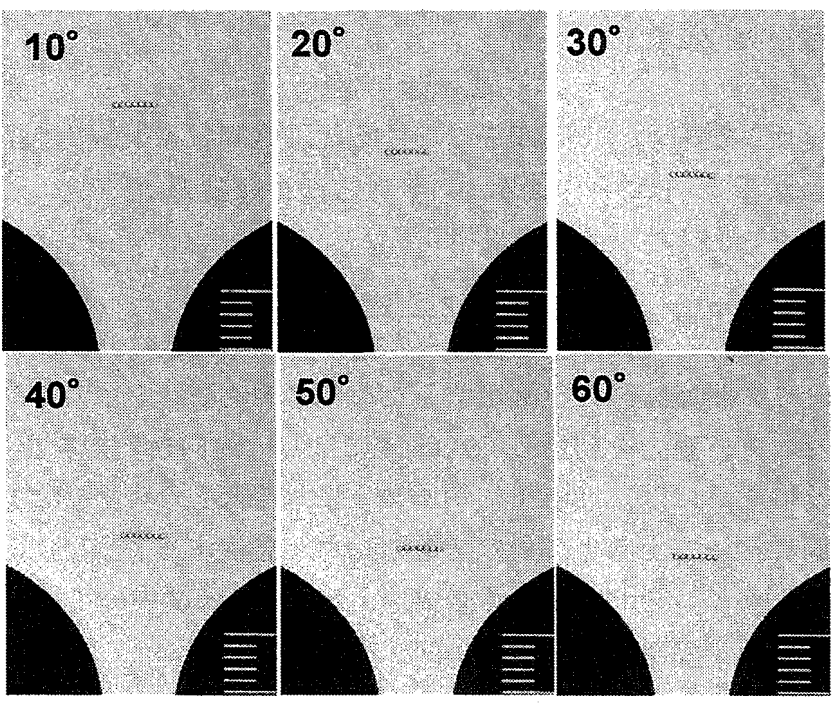

Fig. 6 ポリスチレンビーズの位置の角度依存

〈参考文献〉

(1) $\mathrm{Li} \mathrm{H}$ and Bashir $\mathrm{R}$. Dielectrophoretic separation and manipulation of live and heat-treated cells of Listeria on microfabricated devices with interdigitaed electrodes. Sensors and Actuators 2002; B 86:215-221.

(2)Gascoyne P, Satayavivad J, Ruchirawat M.Microfluidic approaches to malaria detection. Acta Tropica 2004; 89:357-369

(3)Pohl H A. Dielectrophoresis. Cambridge University Press. Cambridge. 1978. 